\title{
Determinan Pertumbuhan Ekonomi Wilayah Pengembangan Jawa Barat Tahun 2014-2018 dengan Pendekatan Regresi Panel Spasial
}

\author{
(Determinants of Economic Growth in the West Java Development Area in 2014-2018 with the
} Spatial Panel Regression Approach)

Dian Noviyanti

Badan Pusat Statistik Kabupaten Bandung Barat

Kantor BPS Kabupaten Bandung Barat, Jln. Raya Padalarang No. 763, Padalarang, Bandung Barat, 40553

E-mail: dian.noviyanti@bps.go.id

\begin{abstract}
ABSTRAK
Pembangunan wilayah adalah upaya mencapai pembangunan berimbang dengan terpenuhinya potensi-potensi pembangunan sesuai kapasitas wilayah/daerah yang beragam. Konsep pembangunan berdimensi kewilayahan di Provinsi Jawa Barat diterapkan melalui pembagian enam wilayah pengembangan (WP). Aspek yang memengaruhi pertumbuhan ekonomi tiap WP perlu diketahui sebagai dasar penyusunan strategi pembangunan. Penelitian ini bertujuan untuk menganalisis faktor-faktor yang memengaruhi perkembangan ekonomi WP Jawa Barat. Analisis data penelitian ini menggunakan metode Geographically Weighted Panel Regression (GWPR). Indikator pertumbuhan ekonomi sebagai variabel dependen yaitu PDRB (produk domestik regional bruto) atas dasar harga konstan (ADHK) 2010. Determinan pertumbuhan ekonomi diteliti dengan menggunakan variabel independen: PDRB pertanian, pembentukan modal tetap bruto (PMTB), rata-rata lama sekolah (RLS), dan jumlah puskesmas. Hasil akhir penelitian menunjukkan faktor yang memengaruhi pertumbuhan ekonomi setiap WP yaitu: PDRB pertanian, PMTB, RLS, puskesmas (WP Bodebekpunjur); PDRB pertanian, PMTB, puskesmas (WP Purwasuka), PDRB pertanian, PMTB (WP Ciayumajakuning, Priatim-Pangandaran, KK Cekungan Bandung), serta PDRB pertanian, PMTB, RLS (WP Sukabumi).
\end{abstract}

Kata kunci: pembangunan, wilayah pengembangan, pertumbuhan ekonomi, GWPR

\begin{abstract}
Regional development is an effort to achieve balanced development by fulfilling development potentials according to the various regional/regional capacities. The concept of development with a regional dimension in West Java Province is applied through the division of six development areas (WP). Aspects that affect the economic growth of each WP need to be known as the basis for formulating a development strategy. This study aims to analyze the factors that influence the economic development of West Java WP. Data analysis of this study used the Geographically Weighted Panel Regression (GWPR) method. The indicator of economic growth as the dependent variable is GRDP (gross regional domestic product) at constant prices (ADHK) 2010. The determinants of economic growth were examined using the independent variable: agricultural GRDP, gross fixed capital formation (PMTB), average length of schooling $(R L S)$, and number of public health center. The final result of the study shows that the factors that influence the economic growth of each WP are: agricultural GRDP, PMTB, RLS, number of public health center (WP Bodebekpunjur); agricultural GRDP, PMTB, number of public health center (WP Purwasuka); agricultural GRDP, PMTB (WP Ciayumajakuning, Priatim-Pangandaran, KK Bandung Basin), and agricultural GRDP, PMTB, RLS (WP Sukabumi).
\end{abstract}

Keywords: development, development area, economic growth, GWPR

\section{PENDAHULUAN}

Pemerataan merupakan salah satu arah paradigma baru pembangunan (Rustiadi, Saifulhakim, \& Panuju, 2009). Tujuan pemerataan yaitu terciptanya kesejahteraan dan pembangunan dapat dinikmati semua lapisan masyarakat. Wilayah Pengembangan (WP) adalah wilayah yang memiliki prioritas dikembangkan berdasarkan karakteristik dan potensi yang dimiliki. Harapan yang hendak dicapai dengan konsep WP yakni terciptanya pusat pertumbuhan baru yang meningkatkan pertumbuhan wilayah tersebut dan wilayah sekitarnya (Latuconsina, 2017). Pusat pertumbuhan baru tersebut diharapkan bisa menjadi pusat kegiatan lokal dan regional (Chairina, 2018). WP dapat dihubungkan dengan pengembangan cluster dalam suatu wilayah. Daerah yang mengembangkan cluster memiliki daya saing tinggi dengan spesialisasi lebih besar, informasi dan organisasi bisnis lebih baik, pengaruh positif jaringan kewirausahaan. 
Jawa Barat adalah provinsi dengan jumlah penduduk terbesar di Indonesia. Berdasarkan data (BPS, 2019) jumlah penduduk Provinsi Jawa Barat sejumlah 48,683,861 jiwa atau $18.37 \%$ dari penduduk Indonesia pada tahun 2018. Pada tahun 2016 LPE Jawa Barat mampu berada pada posisi 5.66\% namun nilai tersebut tidak dapat dipertahankan dan menurun pada titik 5.35\% di tahun 2017. Pertumbuhan ekonomi adalah peningkatan dalam sejumlah komoditas yang dapat digunakan atau diperoleh di suatu wilayah. Model pertumbuhan Solow menyatakan pertumbuhan ekonomi merupakan rangkaian kegiatan yang bersumber pada manusia, akumulasi modal, pemakaian teknologi modern dan output, guna mencapai pertumbuhan ekonomi yang berkesinambungan (Todaro \& Smith, 2006). Menurut (Tirado, Minguela, \& JM, 2016) pertumbuhan ekonomi modern ditandai dengan pemusatan aktivitas industri di lokasi tertentu yang mengakibatkan ketimpangan PDRB perkapita antar wilayah.

Salah satu upaya strategis yang telah dilakukan oleh pemerintah untuk mengatasi ketimpangan pembangunan antar wilayah adalah konsep pembangunan berdimensi kewilayahan. Keterkaitan fungsional antar wilayah pengembangan merupakan strategi yang ditujukan untuk meningkatkan sinergitas dan integrasi pengembangan wilayah antar WP dan Kawasan Khusus (KK) untuk mengurangi kesenjangan pembangunan antarwilayah (BPS, 2017). Berdasarkan Peraturan Daerah Provinsi Jawa Barat Nomor 22 Tahun 2010 tentang Rencana Tata Ruang Wilayah (RTRW) Provinsi Jawa Barat Tahun 2009-2029, wilayah Provinsi Jawa Barat terbagi ke dalam 6 (enam) Wilayah Pengembangan (WP) yaitu:

1.WP Bodebekpunjur, yang mencakup wilayah Kabupaten Bogor, Kabupaten Bekasi, Kota Bekasi, Kota Depok, Kota Bogor.

2.WP Purwasuka, yang meliputi daerah Kabupaten Subang, Kabupaten Purwakarta dan Kabupaten Karawang.

3.WP Ciayumajakuning, yang mencakup Kabupaten Kuningan, Kabupaten Cirebon, Kabupaten Majalengka, Kabupaten Indramayu, Kabupaten Sumedang dan Kota Cirebon.

4.WP Priatim-Pangandaran, yang mencakup Kabupaten Garut, Kabupaten Tasikmalaya, Kabupaten Ciamis,

Kota Tasikmalaya, Kota Banjar dan Kabupaten Pangandaran.

5.WP Sukabumi, wilayahnya mencakup Kabupaten Sukabumi, Kota Sukabumi dan Kabupaten Cianjur.

6.WP Kawasan Khusus Cekungan Bandung, yang meliputi Kabupaten Bandung, Kabupaten Bandung Barat, Kota Cimahi, Kota Bandung.

Penelitian tentang faktor yang memengaruhi pertumbuhan ekonomi dengan regresi panel spasial dilakukan oleh (Husein, 2019) yang menghasilkan variabel PMTB (Pembentukan Modal Tetap Bruto), tenaga kerja, pengeluaran pemerintah dan panjang jalan berpengaruh signifikan positif terhadap pertumbuhan ekonomi kabupaten/kota di Sulawesi Selatan. (Nurwijayati, 2017) meneliti pengaruh indikator komposit IPM terhadap pertumbuhan ekonomi kabupaten/kota di Provinsi DIY menggunakan regresi panel yang menyimpulkan RLS dan paritas daya beli berpengaruh signifikan positif. Determinan pertumbuhan ekonomi kabupaten/kota di Provinsi Bali diteliti (Handayani, Malik, \& Karongkong, 2015) dengan variabel independen jumlah penduduk, Angka Harapan Hidup (AHH), Rata-Rata Lama Sekolah (RLS), dan PDRB per Kapita menggunakan metode analisis deskriptif dan analisis jalur. Faktor yang memengaruhi pertumbuhan ekonomi di Kota Samarinda diteliti (Warsilan \& Noor, 2015) dengan menggunakan metode OLS (Ordinary Least Square) dan variabel puskesmas, air bersih, serta panjang jalan.

Tiap WP Jawa Barat memiliki potensi, karakteristik, keunggulan yang berbeda. Penggalian faktor dominan yang memengaruhi pertumbuhan ekonomi masing-masing WP sangat penting diketahui. Identifikasi aspek sosial, ekonomi, pendidikan tiap WP berguna untuk perumusan strategi pembangunan yang efektif. Faktor-faktor apa saja yang memengaruhi pertumbuhan ekonomi tiap WP Jawa Barat dan seberapa besar pengaruhnya? Pertanyaan tersebut menjadi dasar tujuan penelitian ini yaitu menganalisis faktor-faktor yang memengaruhi pertumbuhan ekonomi WP Jawa Barat. Analisis data dalam penelitian ini memerlukan pertimbangan ruang geografis (spasial) karena adanya keragaman karakteristik dan potensi wilayah. Penggunaan analisis Geographically Weighted Panel Regression (GWPR) merupakan pilihan yang tepat karena menghasilkan estimasi untuk masing-masing WP. Kelebihan lain yaitu GWPR mampu menampilkan aspek ketetanggaan antar wilayah sehingga bisa dibandingkan hasil estimasi pada lokasi yang berdekatan (Lewandowska \& Gwarda, 2018).

\section{METODE}

Penelitian ini dilaksanakan di Provinsi Jawa Barat yang terdiri dari 6 wilayah pengembangan (WP) dan 27 kabupaten/kota. Alat yang digunakan dalam penelitian ini adalah perangkat komputer yang dilengkapi dengan Microsoft Office, Software Geographic Information System (GIS), Software R Studio, dan alat tulismenulis. Perkembangan ekonomi wilayah Jawa Barat dianalisis dengan metode GWPR (Geographically 
Weighted Panel Regression) untuk mengetahui faktor-faktor yang dominan dan berpengaruh pada tiap WP. Permodelan GWPR yang digunakan dalam penelitian ini menggunakan gabungan GWR (Geographically Weighted Regression) dan regresi panel FEM (Fixed Effect Model) seperti yang dilakukan (Rahayu, 2017).

Indikator pertumbuhan ekonomi yang digunakan PDRB ADHK 2010 karena lebih menekankan pada kemampuan daerah untuk meningkatkan PDRB agar melebihi laju pertumbuhan penduduk. Penggunaan variabel PDRB pertanian, PMTB, RLS, dan puskesmas berdasarkan teori pertumbuhan ekonomi klasik Adam Smith yang menyatakan pertumbuhan output suatu negara terdiri dari sumber alam atau faktor produksi, sumber manusia, dan stok barang kapital. Teori lain yaitu teori pertumbuhan endogen yang menyatakan peran investasi berupa modal fisik dan modal manusia menentukan pertumbuhan ekonomi. Menurut (Todaro \& Smith, 2006) akumulasi modal yang meliputi semua bentuk atau jenis investasi baru yang ditanamkan pada tanah, peralatan fisik, dan modal atau SDM merupakan komponen utama pertumbuhan ekonomi. Pendidikan dan kesehatan dapat dilihat sebagai komponen pertumbuhan dan pembangunan yang vital sebagai input fungsi produksi agregat. Peran ganda pendidikan sebagai input maupun output menyebabkan pendidikan sangat penting dalam pembangunan ekonomi.

\section{Regresi Panel}

Data dengan karakteristik panel adalah data yang berstruktur urut waktu (time series) sekaligus antarindividu (cross section). Estimasi model regresi data panel dapat dilakukan dengan tiga pendekatan yaitu common effect model (CEM), fixed effect model (FEM), dan random effect model (REM). Pendekatan CEM dilakukan dengan mengkombinasikan data time series dan cross section lalu melakukan pendugaan (pooling). Pada pendekatan FEM nilai intersep berbeda-beda untuk setiap unit cross section tapi masih mengasumsikan slope atau koefisien tetap. REM merupakan pendekatan estimasi regresi data panel yang mengasumsikan perbedaan intersep pada unit cross section adalah variabel acak (Meutuah, Yasin, \& Maruddani, 2017). Pemilihan pendekatan model regresi panel terbaik dapat dilakukan dengan uji chow dan uji hausman.

1. Uji Chow

Uji Chow digunakan untuk memilih pendekatan CEM atau FEM yang lebih baik digunakan pada model regresi data panel.

2. Uji Hausman

Uji ini digunakan untuk memilih apakah FEM atau REM yang lebih tepat digunakan untuk model regresi data panel terbaik.

\section{Regresi Panel Spasial (GWPR)}

Pada model GWPR, unsur waktu dilibatkan dalam model GWR (Warsito, Yasin, \& D Ispriyanti, 2018). Pengembangan analisis spasial temporal dengan menggabungkan antara model GWR dan model regresi panel untuk pertama kalinya dilakukan oleh (Yu, 2010). Model ini adalah GWPR dengan Fixed Effect Model. Penelitian ini diterapkan pada pengembangan wilayah perekonomian di Beijing. Hasil penelitian tersebut menyimpulkan bahwa model GWPR lebih baik daripada GWR cross-sectional maupun model data panel. Hal senada juga diungkapkan oleh (Bruna \& Yu, 2016) yang menyatakan bahwa metode GWPR mengisi kesenjangan antara GWR dan panel data.

Persamaan model Fixed Effect Geographically Weighted Panel Regression adalah sebagai berikut (Djuraidah, Syafitri, \& Handayani, 2019) :

$$
\mathrm{y}_{\mathrm{it}}=\beta_{0}\left(u_{i}, v_{i}\right)+\sum_{k=1}^{p} \beta_{k}\left(u_{i}, v_{i}\right) \mathrm{X}_{\mathrm{itk}}+\varepsilon_{\mathrm{it}}
$$

dengan:

$\mathrm{y}_{\mathrm{it}} \quad=$ variabel dependen di lokasi pengamatan ke-i pada waktu ke- $\mathrm{t}$

$\mathrm{X}_{\mathrm{itk}} \quad=$ variabel independen ke-k di lokasi pengamatan ke-i waktu ke-t

$\beta_{\mathrm{k}}\left(u_{i}, v_{i}\right)=$ koefisien regresi variabel independen ke-k di lokasi pengamatan ke-i

$\beta_{0}\left(u_{i}, v_{i}\right)=$ Intercept $/$ konstanta lokal pada titik lokasi pengamatan ke-i

$\boldsymbol{\varepsilon}_{\text {it }} \quad=$ residual pengamatan ke-i pada waktu ke-t

$\mathrm{i}=$ pengamatan ke-1,2, $\ldots, n$

$\mathrm{t} \quad=$ waktu ke-1, 2, ., $\mathrm{m}$

$\mathrm{k} \quad=$ variabel independen ke-1,2, ., p

$\mathrm{p} \quad=$ jumlah variabel penjelas/independen

$u_{i}, v_{i} \quad=$ letak bujur ke-i , letak lintang ke-i 
Permodelan GWR dan GWPR dapat dilakukan apabila memenuhi asumsi heterogenitas spasial. Pendeteksian aspek spasial dilakukan dengan uji Breusch Pagan untuk mengetahui adanya keragaman spasial. Hipotesisnya adalah:

$\mathrm{H}_{0}: \sigma_{1}^{2}=\sigma_{2}^{2}=\cdots=\sigma_{n}^{2}=\sigma^{2}$ (tidak ada heterogenitas spasial)

$\mathrm{H}_{1}$ : Paling tidak ada satu $\sigma_{i}^{2} \neq \sigma^{2}$ (ada heterogenitas spasial)

Model GWPR dalam penelitian ini menggunakan bentuk transformasi logaritma natural (ln). Hal ini mengacu pada penelitian Feldstein tahun 1988 yang melakukan transformasi bentuk linear menjadi logaritma natural (ln) guna menghitung nilai elastisitas dari masing-masing variabel independen terhadap variabel dependen ke dalam model. Nilai koefisien slope pada model elastisitas merupakan ukuran elastisitas variabel dependen terhadap independen. Hal ini berarti koefisien slope merupakan tingkat perubahan pada variabel dependen (dalam persen) bila terjadi perubahan pada variabel independen (dalam persen). Model GWPR yang digunakan dalam penelitian ini mengacu pada penelitian (Husein, 2019) dan (Nurwijayati, 2017), spesifikasi model adalah sebagai berikut:

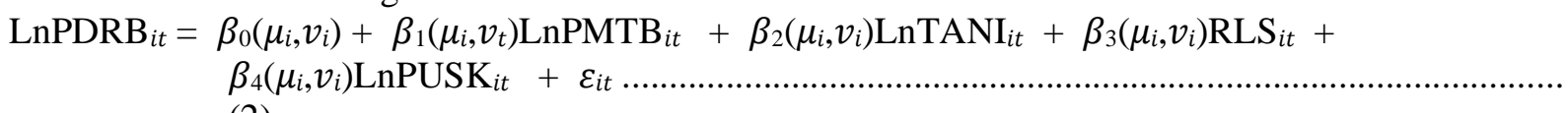

dengan:

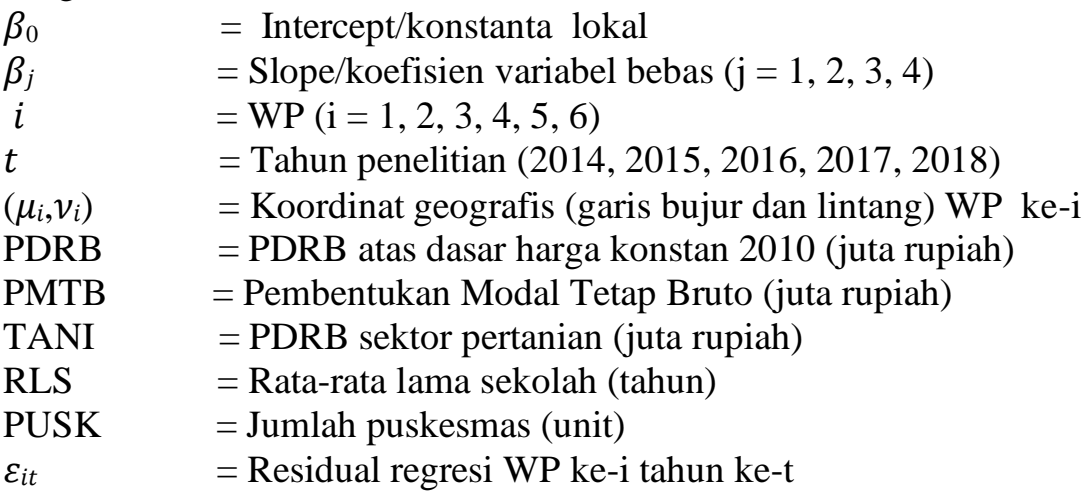

Penelitian ini menggunakan unit analisis WP sehingga data kabupaten/kota anggota tiap WP dirata-rata untuk variabel independen dan dependen. Transformasi data menggunakan bentuk ln bertujuan untuk mengubah skala pengukuran data asli sehingga asumsi-asumsi terpenuhi. Menurut penelitian (Ohyver, 2013) penggunaan transformasi ln menghasilkan model yang memenuhi asumsi normalitas dan bebas multikolinearitas.

Adapun tahapan analisis GWPR sebagai berikut:

1. Melakukan permodelan data panel.

2. Menentukan model data panel terbaik dengan menggunakan Uji Chow dan Uji Haussman.

3. Melakukan uji asumsi regresi panel meliputi uji normalitas, multikolinearitas, autokorelasi

4. Menguji aspek spasial yaitu keragaman spasial dengan Breusch Pagan Test.

5. Melakukan analisis GWPR dengan software RStudio.

6. Menyajikan hasil GWPR dengan peta.

7. Melakukan interpretasi data hasil analisis.

\section{Data dan Sumber Data}

Data yang digunakan dalam penelitian ini adalah data sekunder yang bersumber dari BPS kabupaten/kota dan BPS Provinsi Jawa Barat. Data tersebut meliputi data peta administrasi kabupaten/kota tiap WP (BPS Provinsi Jawa Barat), data PDRB ADHK 2010 tahun 2014-2018 (BPS Provinsi Jawa Barat), data sosial, ekonomi publikasi Jawa Barat dalam angka 2012-2019, data RLS dalam publikasi IPM (BPS Provinsi Jawa Barat), data PDRB menurut lapangan usaha, PDRB menurut pengeluaran (BPS kabupaten/kota Jawa Barat). Data kabupaten/kota yang menjadi anggota tiap WP dirata-rata untuk mendapatkan agregasi data WP. 


\section{HASIL DAN PEMBAHASAN}

\section{Analisis Regresi Data Panel}

Langkah pertama permodelan GWPR yaitu melakukan analisis regresi panel sebagai model global. Terdapat tiga pendekatan model regresi data panel yaitu common effect model (CEM), fixed effect model (FEM), dan random effect model (REM). Pemilihan model regresi panel terbaik dilakukan dengan uji chow dan uji hausman. Hasil uji chow dan hausman terdapat dalam Tabel 1. Nilai p-value uji chow dan hausman pada Tabel 1 bernilai kurang dari taraf signifikansi 1\% (0.01) sehingga $\mathrm{H}_{0}$ ditolak. Konsekuensi penolakan $\mathrm{H}_{0}$ yaitu regresi panel CEM dan REM tidak sesuai untuk digunakan. Regresi panel FEM lebih tepat digunakan pada penelitian ini berdasarkan uji chow dan hausman.

Tabel 1. Hasil uji pemilihan model panel terbaik

\begin{tabular}{lccc}
\hline \multicolumn{1}{c}{ Jenis Uji } & Kriteria uji & Hasil $p$-value & Model terbaik \\
\hline Chow & $\mathrm{H}_{0}:$ CEM dan $\mathrm{H}_{1}:$ FEM & $6.495 \times 10^{-15}$ & FEM \\
Hausman & $\mathrm{H}_{0}:$ REM dan $\mathrm{H}_{1}:$ FEM & $6.650 \times 10^{-9}$ & FEM \\
\hline
\end{tabular}

Langkah selanjutnya yaitu melakukan permodelan regresi panel FEM dengan "within estimator". Hasil analisis data terdapat pada Tabel 2. Pengujian simultan dinyatakan dalam F-statistic yang bernilai 120.517 dengan nilai probability atau $p$-value sebesar $1.0667 \times 10^{-13}$. Taraf signifikansi yang digunakan sebesar $1 \%$ (0.01), sehingga nilai $p$-value dari F-statistic lebih kecil dibandingkan taraf signifikan tersebut. Hal ini berarti bahwa variabel-variabel bebas dalam model secara simultan signifikan memengaruhi pertumbuhan ekonomi Jawa Barat.

Tabel 2. Hasil estimasi regresi panel Fixed Effect Model (FEM)

\begin{tabular}{|c|c|c|c|c|}
\hline Variabel & Koefisien & Standart error & $t$-statistic & Prob (p-value) \\
\hline PMTB & 0.3768 & 0.1134 & 3.3211 & $0.0034 * * *$ \\
\hline TANI & 1.0570 & 0.2425 & 4.3586 & $0.0003^{* * *}$ \\
\hline RLS & 0.0494 & 0.0269 & 1.8381 & $0.0809^{*}$ \\
\hline PUSK & 0.0466 & 0.0246 & 1.8930 & $0.0729 *$ \\
\hline$R$-squared $\left(\mathrm{R}^{2}\right)$ & : & \multicolumn{2}{|c|}{0.9602} & \\
\hline$F$-statistic & : & \multicolumn{2}{|c|}{120.517} & \\
\hline $\operatorname{Prob}(p$-value $)$ & : & \multicolumn{2}{|c|}{$1.0667 \times 10^{-13}$} & \\
\hline
\end{tabular}

Keterangan: signifikan pada taraf nyata $* * * 1 \%, * * 5 \%, * 10 \%$

Hasil regresi panel FEM sebagai model global menghasilkan semua variabel bebas berpengaruh signifikan terhadap pertumbuhan ekonomi Jawa Barat. Berdasarkan uji parsial dengan uji t terlihat variabel PMTB dan PDRB pertanian berpengaruh signifikan terhadap pertumbuhan ekonomi Jawa Barat pada taraf nyata $1 \%$. Adapun RLS dan puskesmas berpengaruh signifikan terhadap pertumbuhan ekonomi Jawa Barat pada taraf nyata $10 \%$. Nilai koefisien determinasi $\left(R^{2}\right)$ sebesar 0.9602 , artinya $96.02 \%$ pertumbuhan ekonomi Jawa Barat dipengaruhi oleh variabel bebas dalam model, sedangkan 3.98\% sisanya dipengaruhi variabel lain di luar model.

\section{Pengujian Asumsi Regresi Data Panel}

Pengujian asumsi regresi data panel dilakukan untuk mengetahui kelayakan model sebagai syarat analisis GWPR. Uji asumsi yang dilakukan meliputi:

a. Uji Normalitas

Uji normalitas mensyaratkan data berdistribusi normal. Uji ini menggunakan uji Shapiro-Wilks dan Jarque-Bera. Hasil output kedua uji tersebut terdapat pada Tabel 3.

Tabel 3. Hasil uji normalitas

\begin{tabular}{llcl}
\hline \multicolumn{1}{c}{ Jenis Uji } & \multicolumn{1}{c}{ Kriteria uji } & Hasil $p$-value & Keputusan \\
\hline Shapiro-Wilks & $\mathrm{H}_{0}:$ Residual berdistribusi normal & 0.4738 & Berdistribusi normal \\
Jarque-Bera & $\mathrm{H}_{1}:$ Residual tidak berdistribusi normal & 0.5748 & Berdistribusi normal \\
\hline
\end{tabular}

Berdasarkan Tabel 3, nilai p-value > tingkat signifikansi $(\alpha=0.05)$ sehingga Ho tidak ditolak dan dapat diambil kesimpulan asumsi normalitas terpenuhi. 
b. Uji Multikolinearitas

Multikolinearitas adalah adanya hubungan linier yang kuat antara beberapa variabel independen. Pada model regresi yang baik,diharapkan tidak terjadi multikolinearitas.Uji multikolinearitas dilakukan dengan melihat nilai VIF (Variance Inflation Factor) atau nilai tolance. Adapun hasil uji tersebut terdapat pada Tabel 4.

Tabel 4. Hasil uji multikolinearitas

\begin{tabular}{cccc}
\hline Variabel X/independen & Nilai VIF & Nilai Tolerance & Keputusan \\
\hline PMTB & 2.998511 & 0.333499 & Tidak terdapat multikolinearitas \\
Tani & 6.948968 & 0.143906 & Tidak terdapat multikolinearitas \\
RLS & 5.771348 & 0.173270 & Tidak terdapat multikolinearitas \\
PUSK & 1.810350 & 0.552379 & Tidak terdapat multikolinearitas \\
\hline
\end{tabular}

Ketentuan model regresi bebas multikolinearitas yaitu bila nilai VIF $<10$ dan nilai Tolerance $>0.10$ (Fahrudin, 2018). Berdasarkan Tabel 4 dapat disimpulkan tidak terdapat multikolinearitas anatar variabel independen pada model regresi panel.

c. Uji Autokorelasi

Autokorelasi mengindikasikan bahwa terdapat korelasi antar anggota sampel atau data pengamatan yang diurutkan berdasarkan waktu, sehingga munculnya suatu datum dipeng aruhi oleh datum sebelumnnya. Pada model regresi diharapkan tidak terdapat autokorelasi. Hasil uji autokorelasi dengan statistik uji DurbinWatson terdapat pada Tabel 5. Pada model regresi panel penelitian ini tidak terjadi autokorelasi karena nilai p-value $>$ tingkat signifikansi $(\alpha=0.05)$, sehingga gagal tolak Ho.

Tabel 5. Hasil uji autokorelasi

\begin{tabular}{clcc}
\hline Jenis Uji & \multicolumn{1}{c}{ Kriteria uji } & Hasil $p$-value & Keputusan \\
\hline Durbin-Watson & $\mathrm{H}_{0}$ : Tidak terdapat autokorelasi & 0.8985 & Tidak terdapat autokorelasi \\
& $\mathrm{H}_{1}:$ Terdapat autokorelasi & & \\
\hline
\end{tabular}

d. Uji Homoskedastisitas

Uji homoskedastisitas bertujuan untuk mengetahi apakah dalam sebuah model regresi memiliki variansi galat yang identik ataukah membentuk pola tertentu. Variansi galat yang membentuk pola tertentu berarti bersifat heteroskedastisitas. Hasil analisis terdapat pada Tabel 6.

Tabel 6. Hasil uji homoskedastisitas

\begin{tabular}{clcc}
\hline Jenis Uji & \multicolumn{1}{c}{ Kriteria uji } & Hasil p-value & Keputusan \\
\hline Breusch-Pagan & $\mathrm{H}_{0}$ : Tidak terdapat heteroskedastisitas & 0.08491 & Terdapat heteroskedastisitas \\
& $\mathrm{H}_{1}$ : Terdapat heteroskedastisitas & & \\
\hline
\end{tabular}

Berdasarkan uji breusch pagan di atas terlihat nilai p-value $<$ tingkat signifikansi $(\alpha=0.10)$ sehingga dapat disimpulkan terjadi pengaruh spasial. Terdapatnya pengaruh lokasi menandakan model regresi panel biasa kurang tepat digunakan. Solusi permodelan regresi dengan keragaman spasial yaitu dengan menggunakan metode GWPR.

\section{Permodelan GWPR}

Permodelan GWPR yang digunakan dalam penelitian ini merupakan regresi panel FEM dengan estimasi within. Konsep estimasi within memerlukan transformasi data asal. Transformasi data dilakukan dengan cara mengurangkan setiap variabel penelitian dengan rata-rata time-series pada masing-masing WP. Estimasi model GWPR diawali dengan menghitung bandwidth (lebar jendela) optimum dan matriks pembobot spasial berdasarkan fungsi Kernel Adaptive Bisquare. Penggunaan fungsi Kernel Adaptive Bisquare karena setelah diujicoba menghasilkan nilai Cross Validation (CV) paling minimum dibanding fungsi kernel lainnya. Hal ini sesuai dengan (Caraka \& Yasin, 2017) yang menyatakan nilai bandwidth optimum akan menghasilkan nilai Cross Validation (CV) minimum. Bandwidth optimum yang diperoleh berbeda untuk setiap WP.

Proses estimasi parameter GWPR dilakukan melalui metode Weighted Least Square (WLS) dengan memberikan pembobot yang berbeda pada setiap WP. Pembobot untuk suatu daerah terhadap daerah lainnya dihitung berdasarkan fungsi Kernel Adaptive Bisquare. Nilai pembobot bergantung pada jarak euclidean titik koordinat geografis (garis lintang dan garis bujur) antar WP dan juga bergantung pada nilai bandwidth masing-masing WP. Proses estimasi GWPR dilakukan pada masing-masing lokasi (enam WP). Hasil estimasi GWPR 
Tabel 7. Hasil estimasi parameter model GWPR WP Jawa Barat

\begin{tabular}{llllll}
\hline \multirow{2}{*}{ WP } & \multicolumn{5}{c}{ Koefisien } \\
\cline { 2 - 5 } & PMTB & TANI & RLS & PUSK & $\mathrm{R}^{2}$ lokal \\
\hline Bodebekpunjur & $0.3203 * *$ & $1.2132 * * *$ & $0.0594 * *$ & $0.0616 * *$ & 0.9768 \\
Purwasuka & $0.3673 * *$ & $1.1771 * * *$ & 0.0388 & $0.0569 * *$ & 0.9748 \\
Ciayumajakuning & $0.4603 * *$ & $0.8940 * *$ & 0.0305 & 0.0197 & 0.9414 \\
Priatim-Pangandaran & $0.4222^{* *}$ & $1.0437 * * *$ & 0.0313 & 0.0150 & 0.9525 \\
KK Cek Bandung & $0.5554 * * *$ & $0.9666^{* *}$ & 0.0211 & 0.0029 & 0.9764 \\
Sukabumi & $0.3202 * *$ & $1.2760 * * *$ & $0.0499 *$ & 0.0414 & 0.9772 \\
\hline
\end{tabular}

$R$-squared $\left(\mathrm{R}^{2}\right)$ keseluruhan model: 0.9721

Keterangan: signifikan pada taraf nyata $* * * 1 \%$, ** 5\%, $* 10 \%$

bersifat lokal, artinya enam WP yang dianalisis memiliki permodelan masing-masing. Pada tiap lokasi dapat diketahui variabel yang signifikan memengaruhi pertumbuhan ekonomi. Hasil estimasi model model GWPR secara ringkas disajikan dalam Tabel 7.

Hasil analisis GWPR menghasilkan variabel PMTB dan PDRB pertanian signifikan positif di semua WP, sedangkan RLS dan puskesmas signifikan positif pada dua WP. PMTB dan PDRB pertanian berpengaruh signifikan positif, artinya kenaikan PMTB dan PDRB pertanian akan menaikkan perkembangan ekonomi wilayah (berpengaruh kuat) di semua WP Jawa Barat. RLS berpengaruh signifikan positif pada WP Bodebekpunjur dan Sukabumi, artinya kenaikan RLS akan meningkatkan perkembangan wilayah di WP tersebut. Jumlah puskesmas berpengaruh signifikan positif terhadap perkembangan ekonomi WP Bodebekpunjur dan Purwasuka artinya penambahan puskesmas akan menaikkan perkembangan ekonomi kedua WP tersebut.

GWPR sebagai model lokal yang telah terbentuk perlu dilihat kesesuaiannya dibandingkan dengan regresi panel FEM sebagai model global. Tabel 8 menunjukkan nilai koefisien determinasi $\left(\mathrm{R}^{2}\right)$ model GWPR lebih besar, artinya model GWPR mampu menjelaskan keragaman perkembangan ekonomi wilayah sebesar 97.21\% dibandingkan model global. Model GWPR memiliki AIC (Akaike Information Criterion) lebih kecil dibanding model global. Menurut (Nachrowi \& H, 2006) model yang memiliki nilai AIC terkecil merupakan model yang lebih baik. RMSE (Root Mean Square Error) mencerminkan besarnya sisaan atau error yang dihasilkan model. Model yang memiliki nilai RMSE paling kecil (GWPR) lebih tepat digunakan dibanding model dengan RMSE relatif besar (regresi panel FEM).

Tabel 8. Perbandingan regresi panel FEM (model global) dan GWPR (model lokal)

\begin{tabular}{cccccc}
\hline No. & Model & Kriteria & Regresi panel FEM & GWPR & Model Terbaik \\
\hline 1. & $\mathrm{R}^{2}(\%)$ & Nilai terbesar lebih baik & 96.02 & 97.21 & GWPR \\
2. & AIC & Nilai terkecil lebih baik & -153.019 & -164.889 & GWPR \\
3. & RMSE & Nilai terkecil lebih baik & 0.085 & 0.071 & GWPR \\
\hline
\end{tabular}

\section{Analisis Faktor-Faktor yang Memengaruhi Pertumbuhan Ekonomi}

\section{a) Pembentukan Modal Tetap Bruto (PMTB)}

Variabel Pembentukan Modal Tetap Bruto (PMTB) berpengaruh signifikan positif pada seluruh WP berdasarkan Gambar 1. Kenaikan PMTB (investasi) secara signifikan akan menaikkan PDRB ADHK di seluruh wilayah Jawa Barat. Pengaruh PMTB terhadap perkembangan ekonomi wilayah sangat kuat di bagian tengah (WP KK Cekungan Bandung) dan berkurang pengaruhnya di bagian timur (WP Ciayumajakuning dan Priatim-Pangandaran). WP bagian barat (Bodebekpunjur dan Sukabumi) dan tengah (Purwasuka) merupakan wilayah dengan pengaruh PMTB terendah terhadap perkembangan ekonomi. KK Cekungan Bandung merupakan WP dengan pengaruh PMTB terhadap perkembangan ekonomi tertinggi, hal ini berarti kenaikan PMTB 1\% akan menaikkan PDRB ADHK 0.5554\%. Pengaruh PMTB terendah terdapat pada WP Sukabumi dsk, artinya kenaikan PMTB 1\% hanya akan menaikkan PDRB ADHK $0.3202 \%$. 


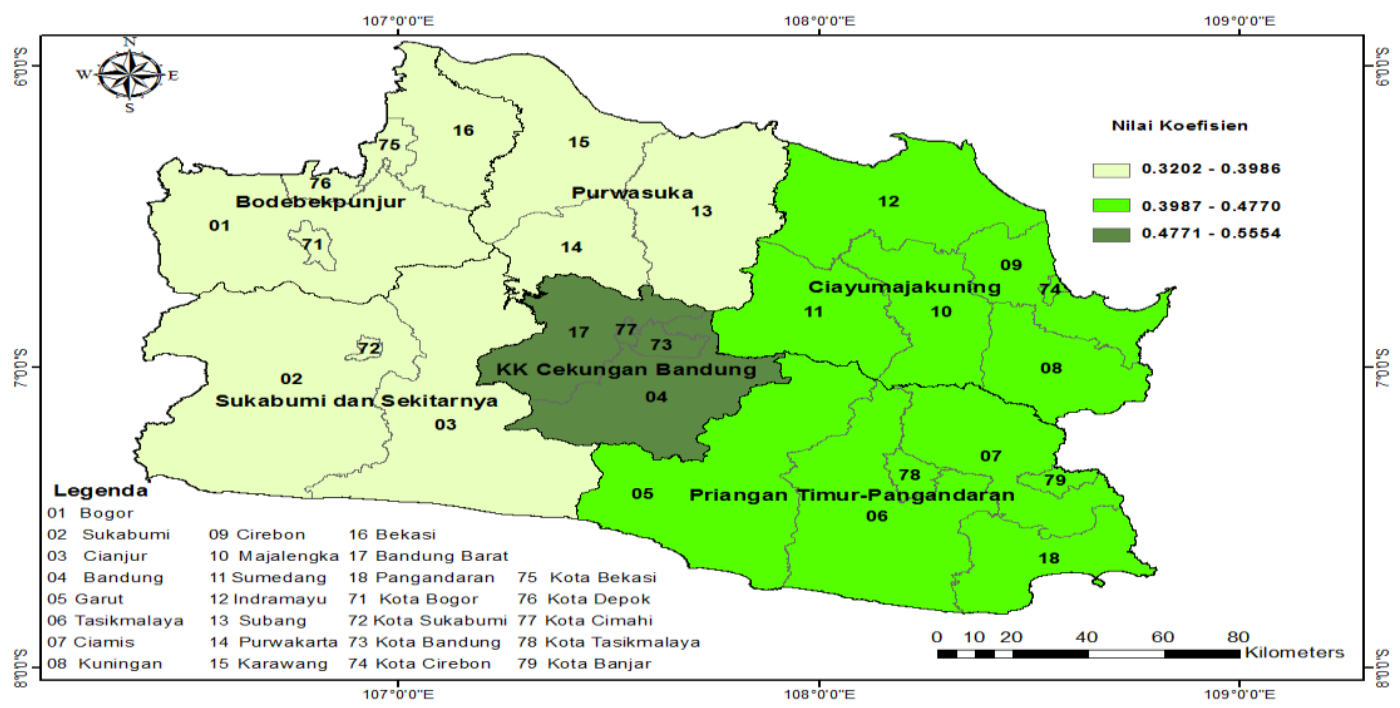

Gambar 1. Peta sebaran estimasi lokal PMTB WP Jawa Barat

\section{b) Variabel PDRB Pertanian}

Variabel PDRB pertanian berpengaruh signifikan positif pada seluruh WP berdasarkan Gambar 2. Hal ini berarti kenaikan nilai PDRB pertanian akan menaikkan PDRB ADHK di seluruh WP Jawa Barat. Pengaruh PDRB pertanian terhadap perkembangan ekonomi sangat kuat di bagian barat (WP Bodebekpunjur, Sukabumi, Purwasuka) dan mengecil pengaruhnya ke bagian tengah dan timur Jawa Barat. Kuatnya pengaruh sektor pertanian di bagian barat menunjukkan wilayah tersebut memiliki potensi pertanian yang tinggi dibanding bagian timur. WP Priatim-Pangandaran merupakan wilayah dengan pengaruh PDRB pertanian kategori sedang. Wilayah dengan pengaruh PDRB pertanian terendah terdapat di WP KK Cekungan Bandung dan Ciayumajakuning. Pengaruh PDRB pertanian terbesar terdapat di WP Sukabumi hal ini berarti kenaikan PDRB pertanian 1\% akan menaikkan PDRB ADHK 1.2760\%. Pengaruh PMTB terendah terdapat pada WP Ciayumajakuning, artinya kenaikan PDRB pertanian $1 \%$ hanya akan menaikkan PDRB ADHK $0.8940 \%$.

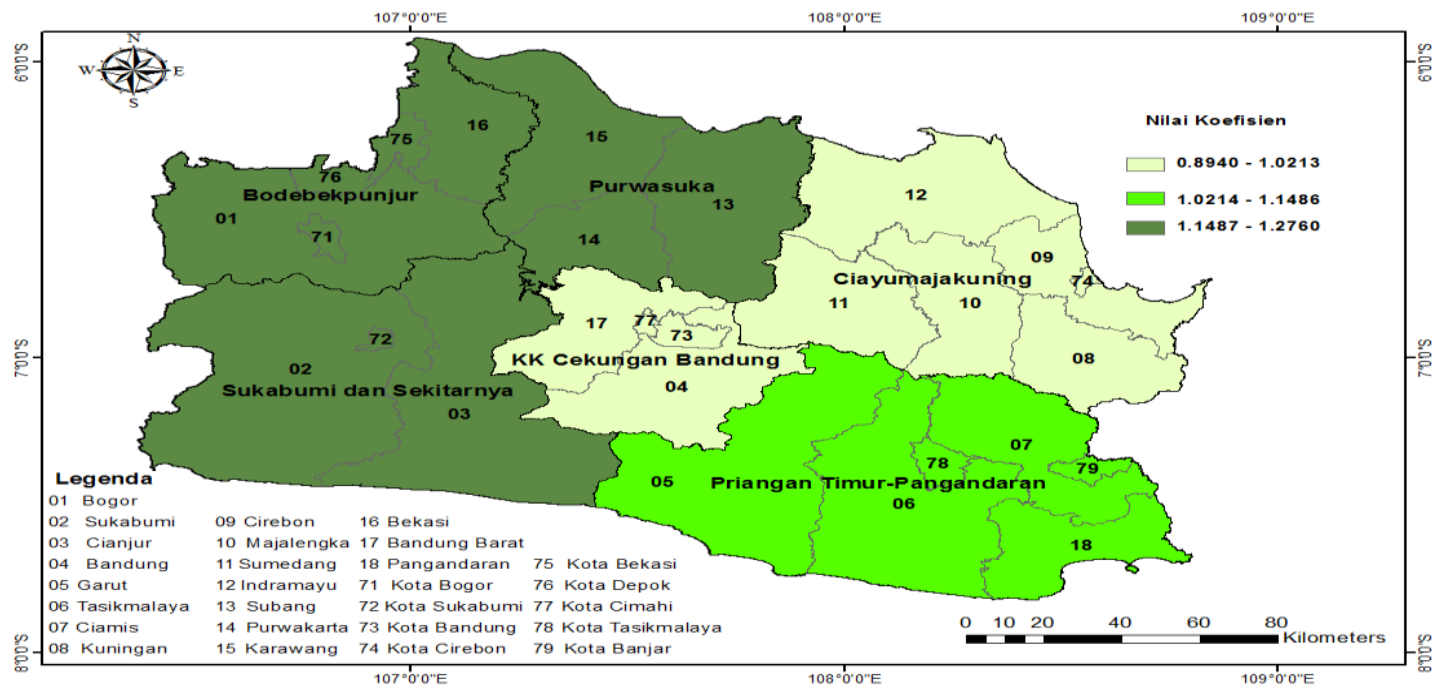

Gambar 2. Peta sebaran estimasi lokal PDRB pertanian WP Jawa Barat

c) Variabel Rata-Rata Lama Sekolah (RLS)

Variabel rata-rata lama sekolah (RLS) berpengaruh signifikan positif di Jawa Barat bagian barat (WP Bodebekpunjur dan Sukabumi) berdasarkan Gambar 3. Hal ini menunjukkan pembangunan sektor pendidikan maju pesat dalam kurun waktu 2014-2018. Kenaikan RLS akan menaikkan PDRB ADHK di dua WP tersebut. Pengaruh RLS terbesar terdapat di WP Bodebekpunjur, hal ini berarti kenaikan RLS 1 tahun akan menaikkan PDRB ADHK $0.0594 \%$. Pengaruh. RLS terendah terdapat pada WP KK Cekungan Bandung 


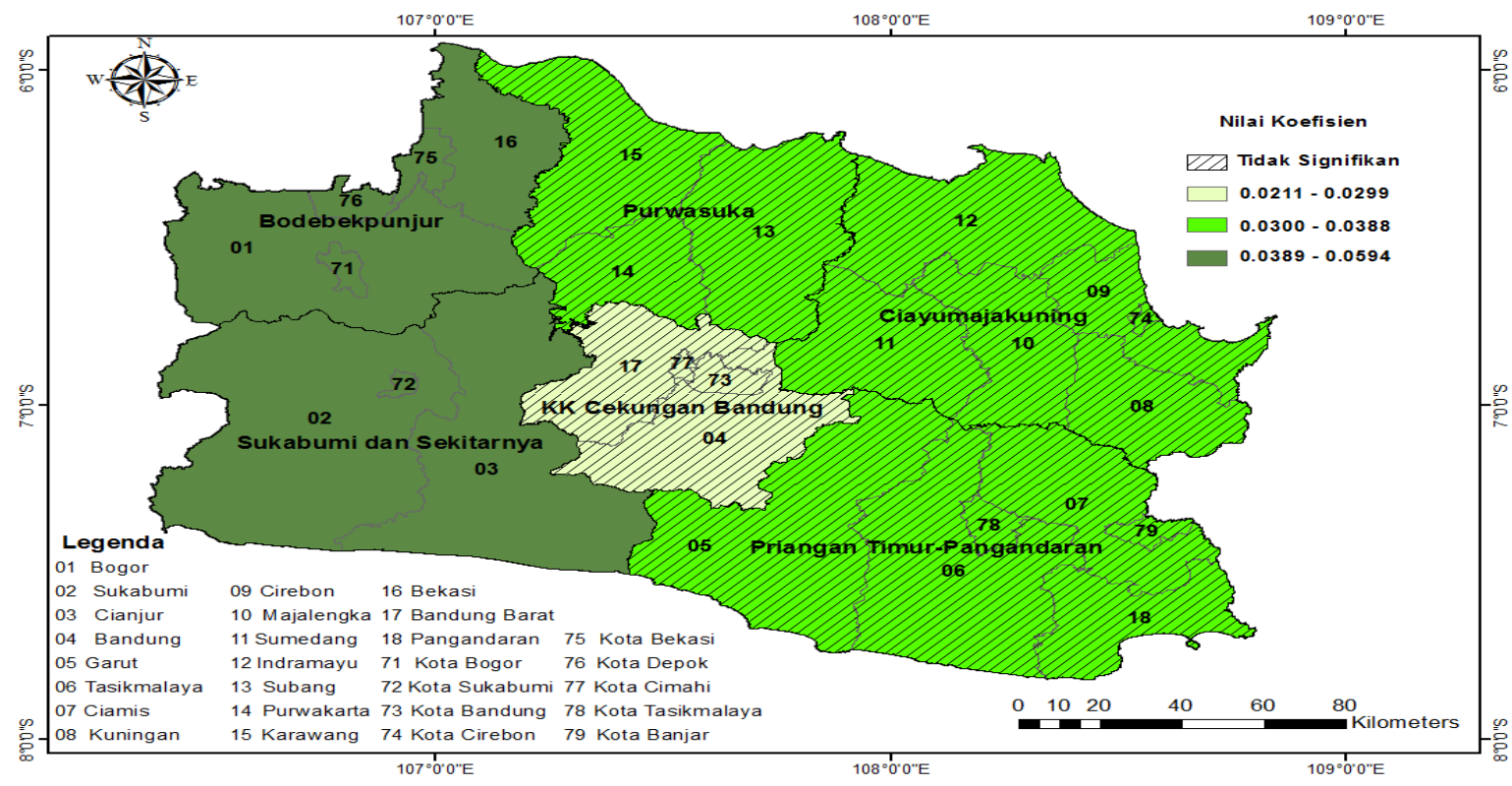

Gambar 3. Peta sebaran estimasi lokal RLS WP Jawa Barat

artinya kenaikan RLS 1 tahun hanya akan menaikkan PDRB ADHK 0.0211\%. Pengaruh positif RLS terhadap pertumbuhan ekonomi pada penelitian ini sejalan dengan penelitian (Handayani, Malik, \& Karongkong, 2015) dan (Nurwijayati, 2017). Penelitian terdahulu tersebut menyimpulkan pengaruh positif RLS terhadap pertumbuhan ekonomi masing-masing di Provinsi Bali dan DIY.

\section{d) Variabel Puskesmas}

Variabel puskesmas berpengaruh signifikan positif pada WP Bodebekpunjur dan Purwasuka berdasarkan Gambar 4. Hal ini menunjukkan rasio puskesmas per jumlah penduduk di dua WP tersebut sudah mendekati ideal (sesuai standar kementerian kesehatan). Kenaikan jumlah puskesmas akan mendorong pertumbuhan ekonomi pada dua WP tersebut. Pengaruh puskesmas terbesar terdapat di WP Bodebekpunjur, hal ini berarti kenaikan puskesmas 1\% akan menaikkan PDRB ADHK 0.0616\%. Pengaruh puskesmas terendah terdapat pada WP KK Cekungan Bandung, artinya kenaikan puskesmas 1\% hanya akan menaikkan PDRB ADHK 0.0029\%. Hasil ini sesuai dengan penelitian (Warsilan \& Noor, 2015) yang meneliti peranan infrastruktur terhadap pertumbuhan ekonomi dan implikasi pada kebijakan pembangunan di Kota Samarinda.

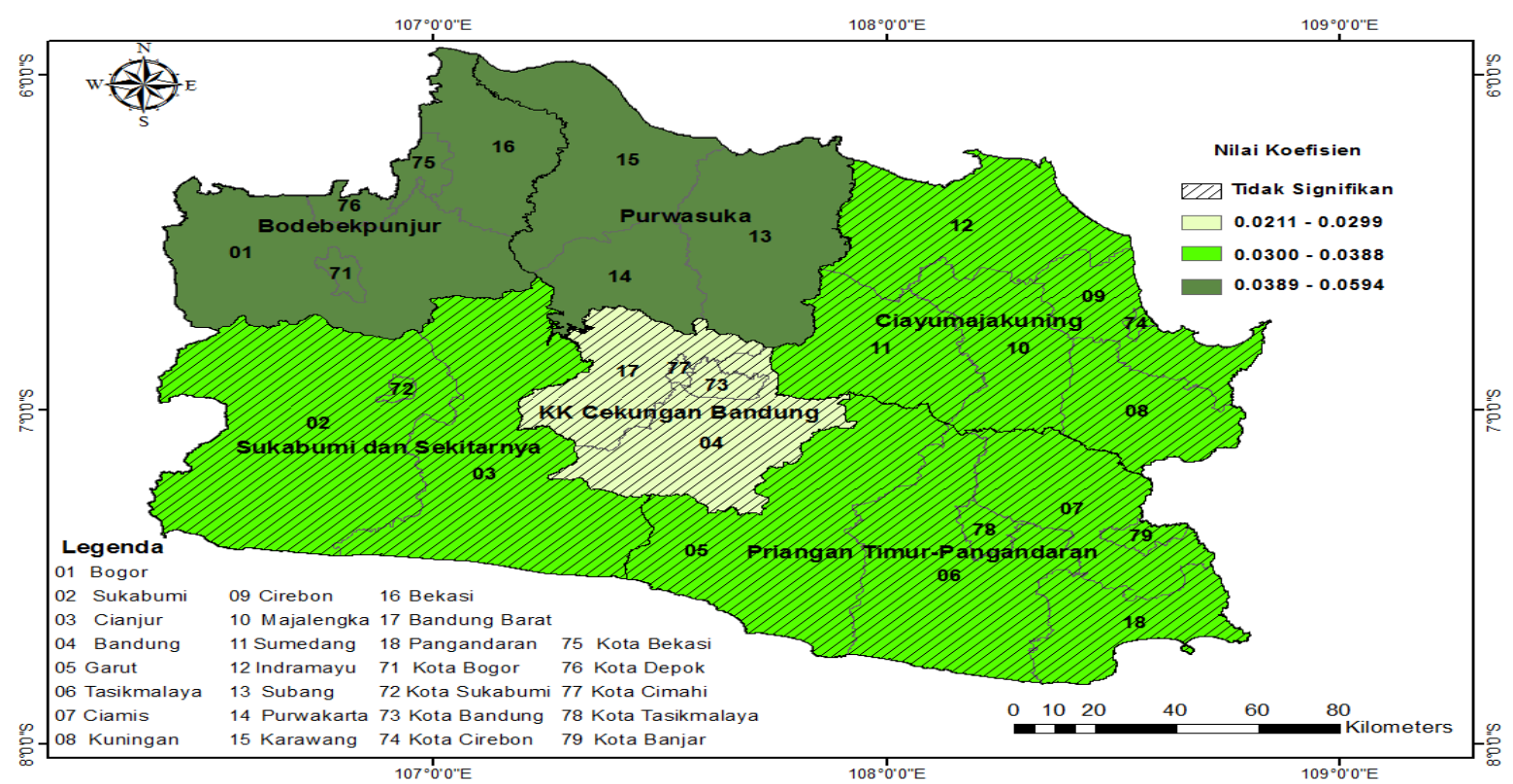

Gambar 4. Peta sebaran estimasi lokal Puskesmas WP Jawa Barat 


\section{Nilai $\mathbf{R}^{2}$ (R-Squared) Lokal}

GWPR menghasilkan model regresi lokal pada tiap lokasi pengamatan (WP) Jawa Barat. Tiap WP memiliki nilai $R$-Squared yang menunjukkan seberapa besar variabel bebas berpengaruh terhadap pertumbuhan ekonomi. Sebaran nilai $\mathrm{R}^{2}$ berbeda-beda tiap wilayah tergantung seberapa kuat pengaruh variabel X terhadap Y. Nilai $\mathrm{R}^{2}$ WP Jawa Barat secara spasial ditampilkan dalam Gambar 5. Nilai R-squared kecil di bagian timur namun bertambah nilainya di bagian tengah dan semakin besar ke arah barat. WP KK Cekungan Bandung, Sukabumi, dan Bodebekpunjur memiliki $\mathrm{R}^{2}$ sangat tinggi dengan nilai mencapai 96.54\%-97.72\%. Hasil ini berarti variabel bebas yang digunakan berpengaruh sangat kuat dalam pertumbuhan ekonomi ketiga WP tersebut. Secara umum R-squared menunjukkan nilai yang relatif tinggi dengan kisaran 94\%-98\%. Hal ini berarti model GWPR pada masing-masing lokasi (WP) memiliki kelayakan yang sangat baik. Koefisien determinasi tertinggi dengan nilai $97.72 \%$ berada pada WP Sukabumi. Hal ini berarti variasi pertumbuhan ekonomi WP Sukabumi dapat dijelaskan oleh variasi variabel bebas sebesar $97.72 \%$, sedangkan $2.28 \%$ sisanya dijelaskan variabel lain di luar model. Nilai goodness of fit terendah terdapat pada WP Ciayumajakuning dengan $\mathrm{R}^{2}$ sebesar $94.14 \%$. Capaian $\mathrm{R}$-squared WP Ciayumajakuning tersebut berarti variasi pertumbuhan ekonominya dapat dijelaskan oleh variasi variabel bebas sebesar $94.14 \%$, sedangkan sisanya (5.86\%) dijelaskan faktor-faktor lain yang tidak disertakan dalam model.

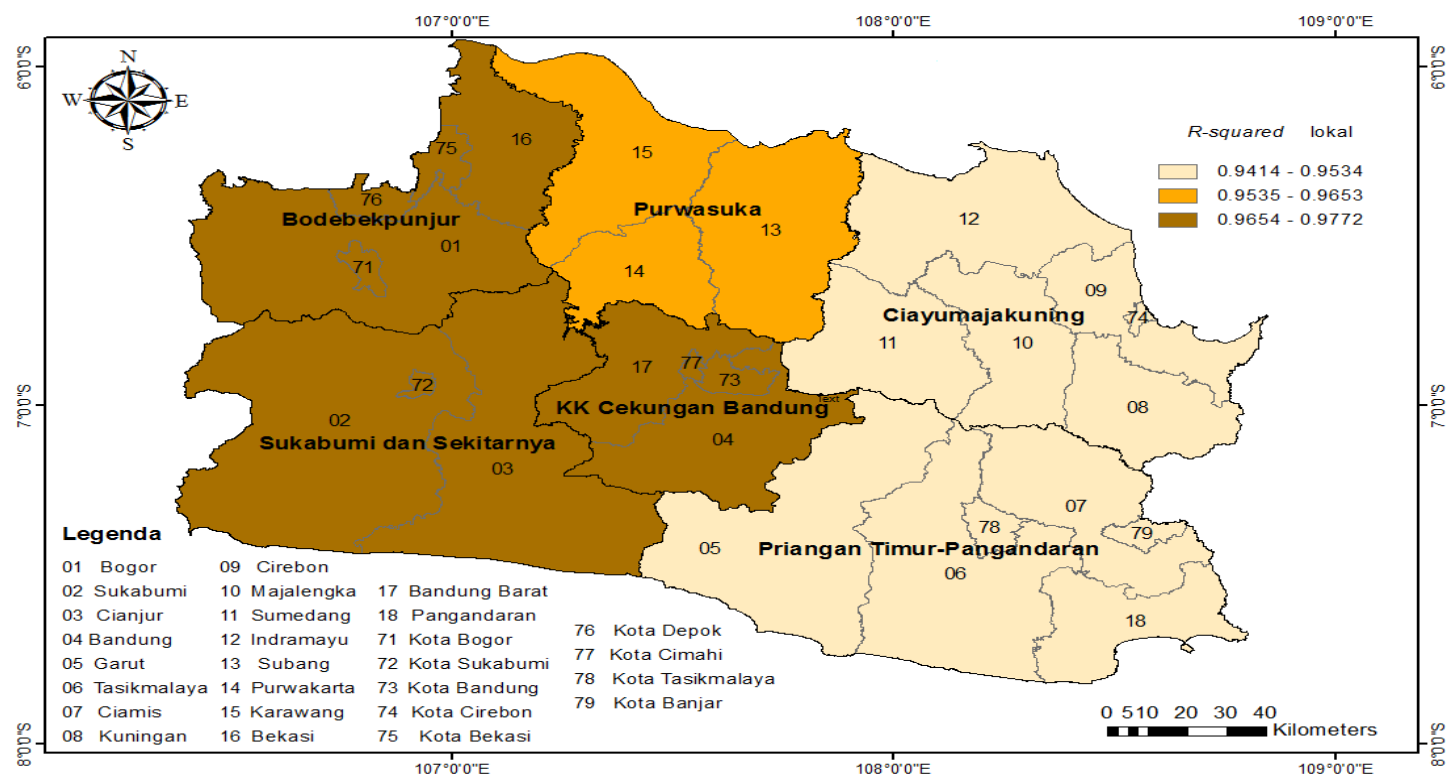

Gambar 5. Sebaran $R$-squared lokal WP Jawa Barat

\section{KESIMPULAN DAN SARAN}

Faktor yang berpengaruh terhadap perkembangan ekonomi WP Bodebekpunjur yaitu faktor ekonomi, pendidikan, dan kesehatan. WP Purwasuka perlu meningkatkan aspek ekonomi dan kesehatan pada strategi pembangunannya. WP di bagian timur dan tengah Jawa Barat (Ciayumajakuning, Priatim-Pangandaran, dan KK Cekungan Bandung) perlu menitikberatkan pembangunan di sektor ekonomi. Peningkatan bidang ekonomi dan pendidikan sangat tepat diterapkan di WP Sukabumi untuk mendukung pertumbuhan ekonomi.

Upaya WP Bodebekpunjur dalam meningkatkan pertumbuhan ekonomi yaitu dengan meningkatkan PMTB, PDRB pertanian, RLS, dan jumlah puskesmas. Langkah strategis dengan meningkatkan investasi dan iklim usaha, pembangunan sektor pendidikan dan kesehatan. WP Purwasuka perlu mendorong peningkatan PMTB, PDRB Pertanian dan jumlah puskesmas. Pembangunan sektor ekonomi perlu ditopang pembangunan bidang kesehatan. Langkah nyata WP Ciayumajakuning, Priatim-Pangandaran, dan KK Cekungan Bandung dalam peningkatan sektor ekonomi yaitu dengan menambah PMTB dan PDRB pertanian. Pembangunan sektor ekonomi menjadi hal yang utama pada WP tersebut. Meningkatkan RLS, PMTB dan PDRB pertanian merupakan penerapan pembangunan bidang pendidikan dan ekonomi di WP Sukabumi. Hal ini dilakukan dengan meningkatkan mutu pendidikan, menambah investasi, dan pembangunan sektor pertanian. Adapun saran terkait pertumbuhan ekonomi wilayah dapat menggunakan variabel penjelas lain, misal Pendapatan Asli Daerah (PAD) sektor pariwisata, tenaga kerja dan sebagainya. 


\section{DAFTAR PUSTAKA}

BPS. (2019). Provinsi Jawa Barat Dalam Angka 2019. Bandung: BPS Provinsi Jawa Barat.

BPS. (2017). Sensus Ekonomi 2016 Analisis Hasil Listing Potensi Ekonomi Jawa Barat. Bandung: BPS Provinsi Jawa Barat.

Bruna, F., \& Yu, D. (2016). Geographically Weighted Panel Regression and Development Accounting for European Regions. International Conference on Regional Science (pp. 1-20). Santiago: Santiago de Compostela.

Caraka, R., \& Yasin, H. (2017). Geographically Weighted Regression (GWR): Sebuah Pendekatan REgresi Geografis. Yogyakarta: Mobius.

Chairina. (2018). Potential Analysis of the Development of Teluk Aru Region in District Level. Internation Journal of Progressive Science and Technologies (IJPSAT) , 517-524.

Djuraidah, A., Syafitri, U., \& Handayani, L. (2019). Estimation of Factors Affecting Gross Regional Domestic Product Using Geographically Weighted Regression (Case Study: Gross Regional Domestic Product in Central Java 2011-2015). International Journal of Ecological Economics and Statistic , $40(1), 1-15$.

Fahrudin, A. (2018). Analisis Pendapatan dan Faktor-Faktor yang Memengaruhi Produksi Usaha Budidaya Tambak Ikan. Efficient Indonesian Journal of Development Economics , 1(1), 77-85.

Handayani, N., Malik, A., \& Karongkong, H. (2015). Pengaruh Jumlah Penduduk, Angka Harapan Hidup, Rata-Rata Lama Sekolah dan PDRB per Kapita terhadap Pertumbuhan Ekonomi di Provinsi Bali. EJournal Ekonomi dan Bisnis Universitas Udayana , 5(10), 3449-3474.

Husein, H. (2019). Disparitas Wilayah dan Konvergensi Pertumbuhan Ekonomi antar Kabupaten/Kota di Provinsi Sulawesi Selatan. Bogor: Institut Pertanian Bogor.

Latuconsina, Z. M. (2017). Analisis Faktor-faktor yang Mempengaruhi Indeks Pembangunan Manusia Kabupaten Malang. Journal of Regional and Rural Development Planning , 1(2): 202-216.

Lewandowska, K., \& Gwarda. (2018). Geographically WEighted Regression in the Analysis of Unemployment in Poland. International Journal of Geo-Information , 7(17), 1-16.

Meutuah, S., Yasin, H., \& Maruddani, D. (2017). Permodelan fixed effect geographically weighted panel regression untuk indeks pembangunan manusia di Jawa Tengah. Jurnal Gaussian , 6(2):241-250.

Nachrowi, N., \& H, U. (2006). Pendekatan Populer dan Praktis Ekonometrika untuk Analisis Ekonomi dan Keuangan. Jakarta: Lembaga Penerbit FE UI.

Nurwijayati, N. (2017). Pengaruh Indikator Komposit Pembangunan Manusia terhadap Pertumbuhan Ekonomi Kabupaten/Kota Provinsi DIY. Jurnal Penidikan dan Ekonomi , 6(6), 520-529.

Ohyver, M. (2013). Penerapan Metode Transformasi Logaritma Natural dan Partial Least Squares untuk Memperoleh Model Bebas Multikolinier dan Outlier. Jurnal Mat Stat, 13(1):42-51.

Rahayu, N. (2017). Geographically weighted panel regression untuk permodelan persentase penduduk miskin di Provinsi Jawa Tengah. Surabaya: Institut Teknologi Sepuluh Nopember.

Rustiadi, E., Saifulhakim, S., \& Panuju, D. (2009). Perencanaan Pengembangan Wilayah. Bogor: Crespent Press dan Yayasan Obor Indonesia.

Tirado, D., Minguela, A., \& JM, G. (2016). Regional Inequality and Economic Development in Spain, 18602010. Journal of Historical Geography, 54(9), 87-98.

Todaro, M., \& Smith, S. (2006). Pembangunan Ekonomi Edisi Kesembilan. Jakarta: Erlangga.

Warsilan, \& Noor, A. (2015). Peranan Infrastruktur terhadap Pertumbuhan Ekonomi dan Implikasi pada Kebijakan Pembangunan di Kota Samarinda. Mimbar, 31(2), 359-366.

Warsito, B., Yasin, H., \& D Ispriyanti, A. H. (2018). The Step Construction of Geographically Weighted Panel Regression in Air Polluter Standard Index (APSI) Data. E3S Web of Conferences 73 (pp. 1-4). Semarang, Indonesia: School of Postgraduate Studies, Diponegoro University .

Yu, D. (2010). Exploring spatiotemporally varying regressed relationships: the geographically weighted panel regression analysis. The international archives of the photometry, remote sensing and spatial information sciences , 38(2):134-139. 